\title{
Denitrification in estuarine sediment stimulated by the irrigation activity of the amphipod Corophium volutator
}

\author{
Sílvia Pedret Pelegrí, Lars Peter Nielsen, Thomas Henry Blackburn
}

Department of Microbial Ecology, Institute of Biological Sciences, University of Aarhus, Ny Munkegade Bd. 540, DK-8000 Aarhus C, Denmark

\begin{abstract}
Sediment with different densities of Corophium volutator (Pallas), ranging from 0 to 19800 ind. $\mathrm{m}^{-2}$, were incubated in laboratory microcosms, and rates of oxygen uptake, denitrification and nitrate ammonification were determined from sediment-water fluxes. The measured processes were stimulated differently by $C$. volutator; oxygen uptake, denitrification of $\mathrm{NO}_{3}^{-}$from nitrification within the sediment, and denitrification of $\mathrm{NO}_{3}^{-}$from the overlying water were enhanced 2-, 3- and 5 -fold respectively in the presence of 19800 ind $\mathrm{m}^{-2}$. This differential stimulation was explained by the different characteristics of diffusional solute transport at the sediment-water interface and mass transfer of water into the burrows where $\mathrm{O}_{2}$ and $\mathrm{NO}_{3}^{-}$was depleted. Denitrification rates were calculated by using the ${ }^{15} \mathrm{~N}$ isotope pairing technique. The applicability of the ${ }^{15} \mathrm{~N}$ isotope pairing technique for measuring coupled nitrification-denitrification in bioturbated sediment was confirmed in a test incubation with different levels of ${ }^{15} \mathrm{NO}_{3}^{-}$added to microcosms with $12000 \mathrm{C}$. volutator ind. $\mathrm{m}^{-2}$
\end{abstract}

KEY WORDS: Denitrification · Bioturbation · Estuarine sediment

\section{INTRODUCTION}

Nitrogen has been identified as the most limiting nutrient for phytoplankton production in coastal seas (e.g. Ryther \& Dunstan 1971) and denitrification may therefore control eutrophication by eliminating available nitrogen through $\mathrm{NO}_{3}{ }^{-}$reduction to $\mathrm{N}_{2} \mathrm{O}$ and $\mathrm{N}_{2}$ (e.g. Nixon et al. 1976, Seitzinger 1980). Bottomdwelling animals affect both physical and chemical processes taking place in the sediment through burrow construction, bioturbation and irrigation (Rhoads 1974 , Aller 1988, Kristensen 1988). The objective of the present study was to measure the effect of bioturbation by the amphipod Corophium volutator (Pallas) on denitrification in estuarine sediments.

Corophium volutator lives in ' $U$ '-shaped burrows 2 to $6 \mathrm{~cm}$ deep that are continuously irrigated. The burrow represents an extension of the sediment surface, and thus of all processes taking place at the surface (Hylleberg \& Henriksen 1980, Kristensen 1984). The burrow wall is often a site of high bacterial numbers and meta- bolic activity compared to bulk sediment (Aller \& Yingst 1978, Henriksen et al. 1983, Koike \& Mukai 1983, Kristensen et al. 1985, 1991, Kristensen \& Blackburn 1987). Higher potential nitrification rates have been reported in C. volutator's burrow wall relative to surface sediment, suggesting better conditions for nitrifiers (Henriksen et al. 1983). The same authors indicated that $C$. volutator's excretion rates could account for $80 \%$ of the net $\mathrm{NH}_{4}{ }^{+}$flux from the sediment and eventually constitute an important pool of $\mathrm{NH}_{4}{ }^{+}$for nitrifying bacteria. Irrigation of the burrow increases $\mathrm{NO}_{3}{ }^{-}$transport from the water column into the sediment and thus denitrification of $\mathrm{NO}_{3}{ }^{-}$coming from the overlying water (Aller 1988, Kristensen 1988), while $\mathrm{O}_{2}$ transport to the burrow lining may increase nitrification (Aller 1988, Kristensen 1988) and thus denitrification of $\mathrm{NO}_{3}{ }^{-}$generated within the sediment. Henriksen et al. (1980) reported, from indirect calculations, higher nitrification and denitrification rates in sediment bioturbated by $C$. volutator ( 6000 ind $\mathrm{m}^{-2}$ ) relative to nonbioturbated sediment. 
The isotope pairing technique (Nielsen 1992), involving ${ }^{15} \mathrm{NO}_{3}^{-}$, makes possible the measurement of denitrification of $\mathrm{NO}_{3}^{-}$coming from both sources: the overlying water (dw) and nitrification within the sediment (dn). Oxygen consumption, $d w$ and $d n$ rates were measured and compared in sediment microcosms containing different amphipod densities and with different $\mathrm{NO}_{3}^{-}$concentrations in the overlying water.

\section{MATERIAL AND METHODS}

Test incubation. A small incubation series was set up to test the applicability of the denitrification assay in sediment bioturbated by Corophium volutator. Specimens approximately 3 to $5 \mathrm{~mm}$ in length were collected in a shallow mesohaline estuary (Norsminde Fjord, Denmark). The amphipods were placed in cores $(13 \mathrm{~cm}$ long and $3.4 \mathrm{~cm}$ inner diameter, containing $6 \mathrm{~cm}$ intact sandy sediment), at a density of 12000 ind. $\mathrm{m}^{-2}$. The amphipods dug immediately into the sediment. The microcosms, covered with a $340 \mu \mathrm{m}$ net to prevent the specimens from escaping, were placed in a reservoir containing aerated in situ water ( $24 \%$ salinity), and kept in darkness at $13^{\circ} \mathrm{C}$. After $1 \mathrm{~d},{ }^{15} \mathrm{NO}_{3}^{-}$was added to each core to give concentrations ranging from 15 to $330 \mu \mathrm{M} \mathrm{NO}_{3}^{-}$and the cores were stoppered. Incubation time was around $80 \mathrm{~min}$ for all the cores, ensuring a maximum oxygen depletion of $20 \%$. Stoppers were removed at the end of the incubation and $\mathrm{ZnCl}_{2}$ (240 $\mu \mathrm{l} 50 \%$ solution) was added to stop microbial activity. Water column and porewater was gently mixed with a stick, and samples of the slurry were stored in $12 \mathrm{ml}$ glass tubes containing $2 \% \mathrm{ZnCl}_{2}$ closed with gastight caps. Two days later, $\mathrm{N}_{2}$ gas was extracted from these water samples with $1 \mathrm{ml}$ argon before analysis.

Main incubation. Corophium volutator was distributed in artificial microcosms containing homogenized and sieved (500 $\mu \mathrm{m}$ mesh) silty sediment. Three different sets of microcosms were used: 0, 6600 (normal density) and 19800 (high density) ind. C. volutator $\mathrm{m}^{-2}$. The experiment was run at $11^{\circ} \mathrm{C}$. Oxygen fluxes were measured regularly to ensure steady state conditions before the experiment was conducted (results not shown). Twelve days after setup, ${ }^{15} \mathrm{NO}_{3}^{-}$was added to the reservoir to give $72 \pm 2 \mu \mathrm{M} \mathrm{NO}_{3}^{-}(80 \pm$ $1 \%{ }^{15} \mathrm{NO}_{3}{ }^{-}$). One day later an incubation was carried out. The cores were stoppered during a period ranging from 0.5 to 4 h (to assure maximum $20 \%$ oxygen depletion). At the end of the incubation the stoppers were removed and $30 \mathrm{ml}$ water samples were taken with a $50 \mathrm{ml}$ plastic syringe. Dissolved $\mathrm{N}_{2}$ was extracted with $5 \mathrm{ml}$ argon and collected in a pre- evacuated $3.4 \mathrm{ml}$ Venoject blood collection tube (Risgaard-Petersen et al. 1993). Water samples for analyzing $\mathrm{NO}_{3}^{-}, \%{ }^{15} \mathrm{NO}_{3}^{-}$, and ${ }^{15} \mathrm{NH}_{4}{ }^{+}$were collected and frozen. The water in the reservoir was subsequently exchanged with water containing $152 \pm 7 \mu \mathrm{M}$ $\mathrm{NO}_{3}^{-}\left(90 \%{ }^{15} \mathrm{NO}_{3}^{-}\right)$and the microcosms were incubated again following the same steps as described above. Mortality at the end of the experiment (17 d after setup) was around $20 \%$ of the initial number of amphipods introduced. Dead amphipods were removed each day from the microcosms.

Analysis. Oxygen was measured directly in the microcosms with an oxygen microsensor provided with a guard cathode (Revsbech 1989) and $\mathrm{NO}_{3}^{-}$plus $\mathrm{NO}_{2}^{-}$ by standard methods (Grasshoff et al. 1983) in a flow injection analyzer (Tecator, Höganäs, Sweden). The formation of ${ }^{15} \mathrm{~N}$-labelled dinitrogen pairs $\left({ }^{14} \mathrm{~N}^{15} \mathrm{~N}\right.$ and ${ }^{15} \mathrm{~N}^{15} \mathrm{~N}$ ) by denitrification was measured on an isotope ratio mass spectrometer as described by Nielsen (1992). The $\%{ }^{15} \mathrm{NO}_{3}{ }^{-}$enrichment in the water phase was analyzed on a mass spectrometer after using denitrifying bacteria cultures to transform $\mathrm{NO}_{3}^{-}$to gaseous $\mathrm{N}_{2}$ (Risgaard-Petersen et al. 1993). Accumulation of ${ }^{15} \mathrm{NH}_{4}{ }^{+}$in the water phase was analyzed by mass spectrometry after $\mathrm{NH}_{4}^{+}$in the samples was liberated as $\mathrm{NH}_{3}$ into a headspace (after addition of an strong base), captured in a capsule containing acidified $\mathrm{Al}_{2} \mathrm{O}_{3}$, and converted to dinitrogen by heating the sample (Blackburn 1993). Due to the small concentrations, the water samples were enriched with $3 \mu \mathrm{mol}$ unlabelled $\mathrm{NH}_{4}{ }^{+}$to obtain sufficient $\mathrm{N}$ for analysis on the mass spectrometer.

Calculations. Denitrification rates were calculated by using the ${ }^{15} \mathrm{~N}$ isotope pairing technique (Nielsen 1992), which assumes that addition of ${ }^{15} \mathrm{NO}_{3}{ }^{-}$does not influence denitrification of the natural ${ }^{14} \mathrm{NO}_{3}^{-}$and that the $\mathrm{NO}_{3}^{-}$species are uniformly mixed in the denitrification zone. The formation rates of single-labelled $\left({ }^{14} N^{15} N\right)$ and double-labelled $\left({ }^{15} N^{15} N\right)$ dinitrogen pairs were used to calculate $d w$ and $d n$ :

$$
\begin{aligned}
& d_{15}=\left({ }^{14} N^{15} N\right)+2\left({ }^{15} N^{15} N\right) \quad \text { (Koike \& Hattori 1978); } \\
& d_{14}=d_{15} \frac{\left({ }^{14} N^{15} N\right)}{2\left({ }^{15} N^{15} N\right)} ; \\
& d w=d_{15} \frac{100}{e_{15}} ; \\
& d n=d_{14}+d_{15}-d w
\end{aligned}
$$

where $e_{15}$ is the $\%{ }^{15} \mathrm{NO}_{3}^{-}$enrichment of the reservoir water.

An analysis of variance (ANOVA) was carried out to test the significance of the differences between treatments. 

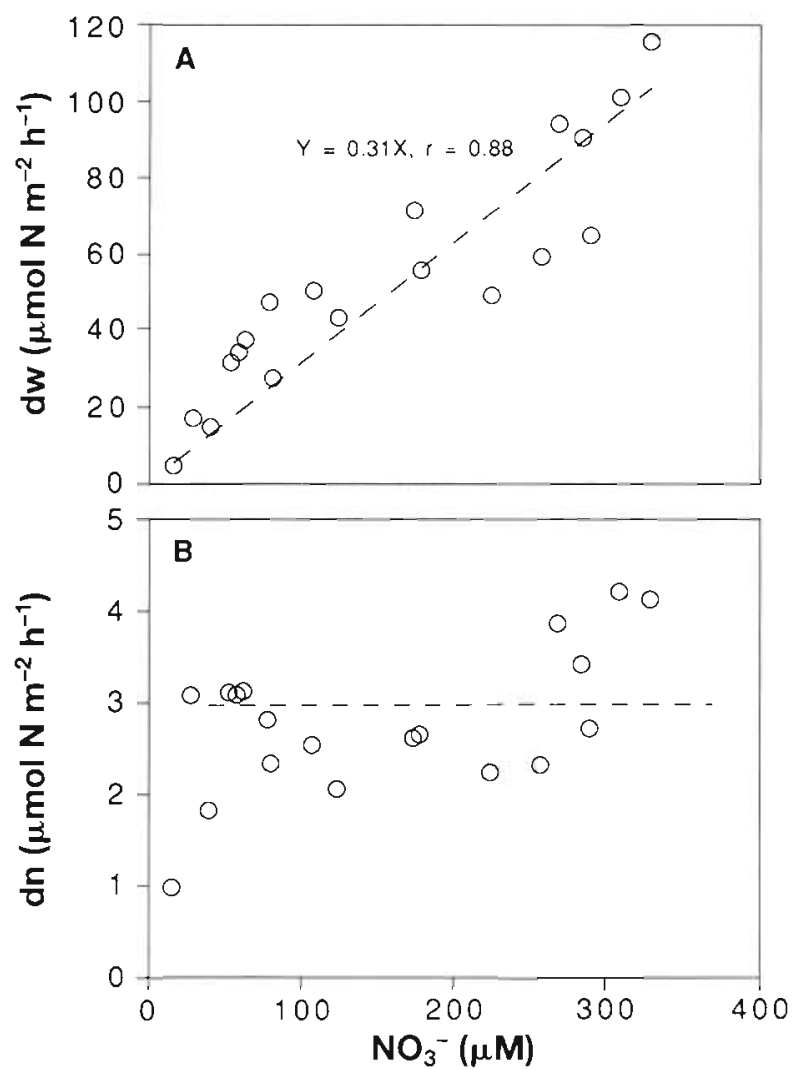

Fig. 1 Corophium volutator. Test incubation. Denitrification rates in intact sediment cores containing 12000 ind. $\mathrm{m}^{-2}$, versus $\mathrm{NO}_{3}^{-}$concentration in the overlying water. Denitrification of $\mathrm{NO}_{3}^{-}$(A) coming from the overlying water ( $d w$ ) and (B) produced within the sediment by nitrification (dn). Each data point represents 1 core

\section{RESULTS}

\section{Test incubation}

Fig. 1A, B shows the calculated rates of denitrification of $\mathrm{NO}_{3}{ }^{-}$coming from the overlying water ( $\mathrm{dw}$ ) and $\mathrm{NO}_{3}^{-}$generated within the sediment (dn). Denitrification of $\mathrm{NO}_{3}^{-}$coming from the overlying water was linearly correlated with $\mathrm{NO}_{3}^{-}$concentration in the overlying water $(\mathrm{r}=0.88)$ in the test incubation with 12000 ind. Corophium volutator $\mathrm{m}^{-2}$ (Fig. 1A). The calculated rates of dn were independent of the concentration of $\mathrm{NO}_{3}^{-}$present in the overlying water at concentrations above $40 \mu \mathrm{M}$ (slope not significantly different from zero, $p=0.05$ ) (Fig. 1B). Oxygen consumption rates (not shown) were $1200 \pm 200 \mu \mathrm{mol} \mathrm{O} \mathrm{m}^{-2} \mathrm{~h}^{-1}$.

\section{Main incubation}

Oxygen consumption rates and denitrification rates were higher in bioturbated than in non-bioturbated

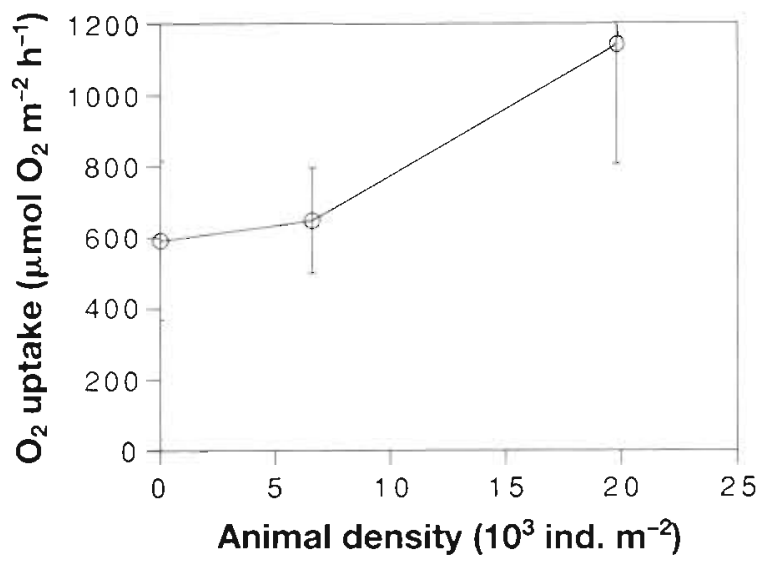

Fig. 2. Corophium volutator. Main incubation. Oxygen consumption rates $( \pm \mathrm{SE})$ in cores with densities ranging from 0 to 19800 ind. $\mathrm{m}^{-2}$

sediments (Figs. 2, $3 \& 4$ ). Both oxygen uptake and dn rates were significantly higher in microcosms containing 19800 ind. $\mathrm{m}^{-2}$ than in microcosms without amphipods $(p<0.001)$, while no statistically significant difference was found between the rates measured in microcosms containing 0 and 6600 ind. $\mathrm{m}^{-2}$ $(\mathrm{p}=0.1)$ (Figs. $2 \& 4)$. Oxygen consumption rates by Corophium volutator, calculated from the literature (McLusky 1969, Birklund 1977), indicated that the amphipod metabolism accounted for less than $2 \%$ of the total sediment oxygen uptake in our bioturbated microcosms. Denitrification of $\mathrm{NO}_{3}^{-}$coming from the overlying water also increased with increasing $\mathrm{NO}_{3}^{-}$ concentration in the overlying water (from 0 to $152 \mu \mathrm{M}$ ) (Fig. 3). Apparent rates of denitrification of $\mathrm{NO}_{3}^{-}$generated within the sediment were not affected by the $\mathrm{NO}_{3}^{-}$concentration present in the overlying water $(p=0.05)$ but increased with amphipod density

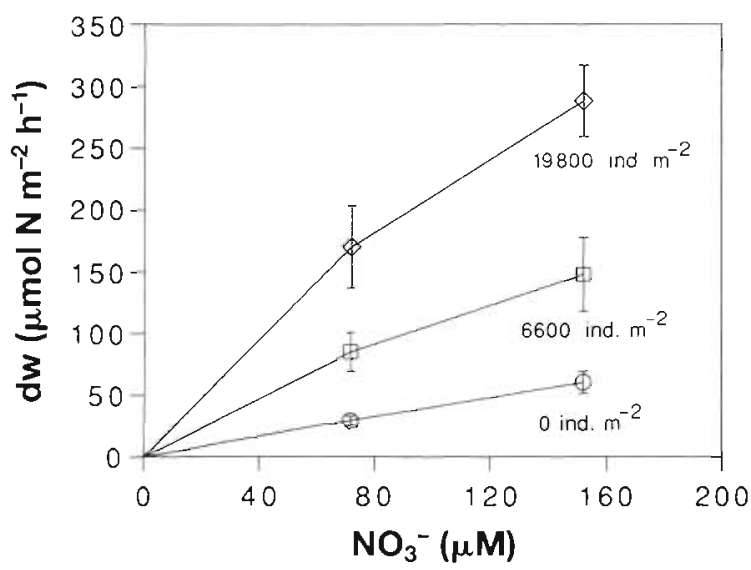

Fig. 3. Corophium volutator. Main incubation. Denitrification rates of $\mathrm{NO}_{3}^{-}$coming from the overlying water ( $\mathrm{dw} \pm \mathrm{SE}$ ) related to $\mathrm{NO}_{3}^{-}$concentration in the water phase, in artificial microcosms with densities of 0,6600 and 19800 ind. $\mathrm{m}^{-2}$ 


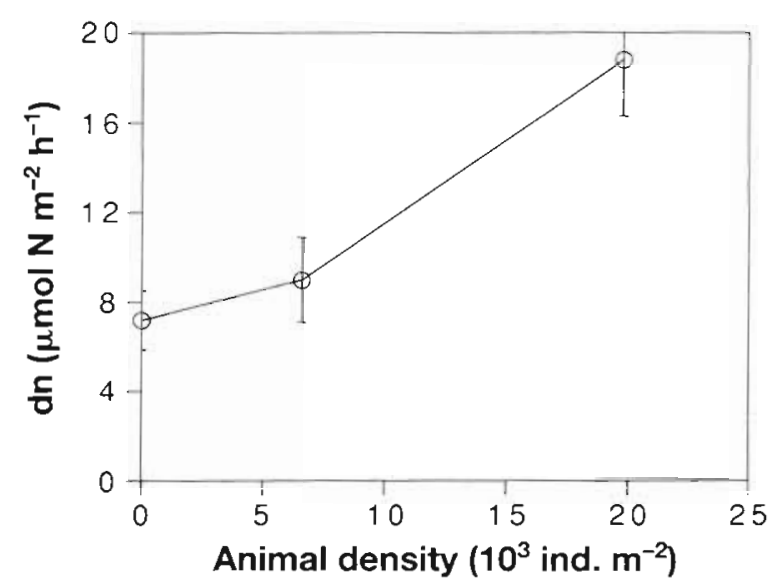

Fig. 4. Corophium volutator. Main incubation. Denitrification rates of $\mathrm{NO}_{3}{ }^{-}$generated within the sediment $(\mathrm{dn} \pm \mathrm{SE}$ ) versus density

(Fig. 4). Nitrate ammonification (Fig. 5), only measured at the highest $\mathrm{NO}_{3}^{-}$concentration, was also higher at greater C. volutator densities. Less than $5 \%$ of the ${ }^{15} \mathrm{NO}_{3}$ reduced was recovered as ${ }^{15} \mathrm{NH}_{4}^{+}$. Denitrification was shown to be the only significant $\mathrm{NO}_{3}^{-}$ reducing pathway in these sediments.

Oxygen consumption, $\mathrm{dn}$ and $\mathrm{dw}$ were stimulated 2-, 3-and 5-fold in sediment inhabited by Corophium volutator (19800 ind. $\mathrm{m}^{-2}$ ) when compared with nonbioturbated sediment (Fig. 6).

\section{DISCUSSION}

Calculation of coupled nitrification-denitrification rates by the ${ }^{15} \mathrm{~N}$ isotope pairing technique assumes uniform mixing of both $\mathrm{NO}_{3}^{-}$species $\left({ }^{15} \mathrm{NO}_{3}^{-}\right.$and

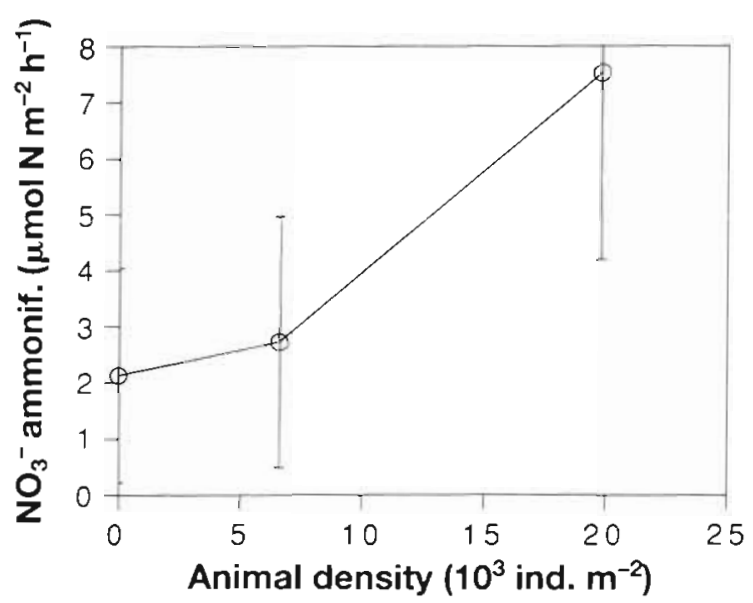

Fig. 5. Corophium volutator. Main incubation. Nitrate ammonification rates $( \pm \mathrm{SE}$ ) versus density in microcosms containing $152 \mu \mathrm{M} \mathrm{NO}_{3}{ }^{-}$in the overlying water

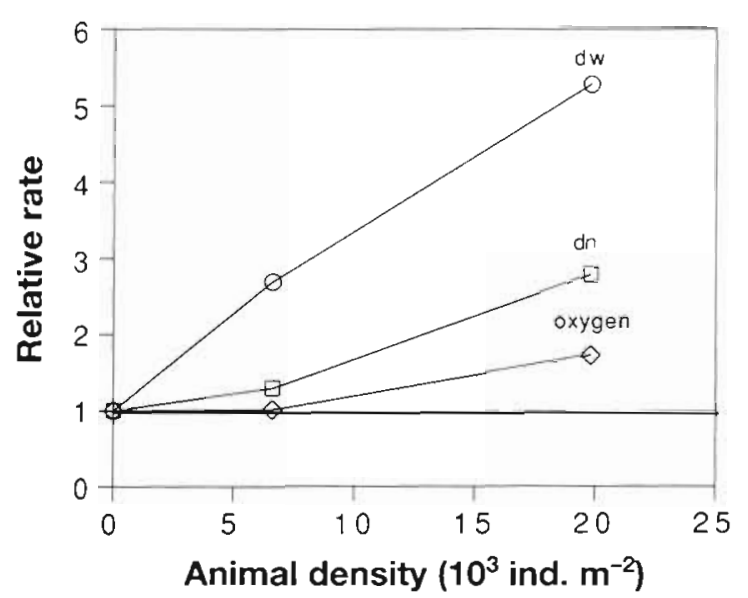

Fig. 6. Corophium volutator. Main incubation. Relative stimulation of $\mathrm{O}_{2}$ uptake, denitrification of $\mathrm{NO}_{3}{ }^{-}$coming from the overlying water ( $\mathrm{dw}$ ) and denitrification of $\mathrm{NO}_{3}^{-}$produced within the sediment by nitrification $(d n)$, by amphipods at different densities. The relative stimulations are rates measured in bioturbated microcosms divided by rates measured in non-bioturbated microcosms. The thick line at a

relative rate of 1 represents amphipod-free microcosms

${ }^{14} \mathrm{NO}_{3}^{-}$) in the denitrification zone (Nielsen 1992). This is because production of unlabelled $N_{2}\left({ }^{14} \mathrm{~N}^{14} \mathrm{~N}\right)$ by denitrification is not measured directly but estimated from the production of single-labelled $\mathrm{N}_{2}\left({ }^{15} \mathrm{~N}^{14} \mathrm{~N}\right)$ relative to double-labelled $\mathrm{N}_{2}\left({ }^{15} \mathrm{~N}^{15} \mathrm{~N}\right)$. Bioturbation may create local or temporal variations in the ratio of $d w$ to $d n$, thus questioning the assumption of the technique. The possible underestimation of dn can be tested in incubations with different concentrations of ${ }^{15} \mathrm{NO}_{3}^{-}$(Nielsen 1992): at higher ${ }^{15} \mathrm{NO}_{3}^{-}$levels, more ${ }^{14} \mathrm{NO}_{3}{ }^{-}$will be paired with ${ }^{15} \mathrm{NO}_{3}{ }^{-}$to form measurable ${ }^{15} \mathrm{~N}^{14} \mathrm{~N}$ and less of the immeasurable ${ }^{14} \mathrm{~N}^{14} \mathrm{~N}$ is formed. The degree of underestimation will therefore diminish at higher ${ }^{15} \mathrm{NO}_{3}{ }^{-}$levels. Too high ${ }^{15} \mathrm{NO}_{3}^{-}$concentrations, however, will affect the assumed first-order kinetics of denitrification, therefore the optimal ${ }^{15} \mathrm{NO}_{3}^{-}$ concentration range has to be tested. The test of the present sediment with Corophium volutator showed that ${ }^{15} \mathrm{NO}_{3}{ }^{-}$concentrations above $40 \mu \mathrm{M}$ did not affect the estimate of $\mathrm{dn}$, an indication that the heterogeneity effect was eliminated and the estimates represented true dn rates (Fig. 1B). First-order kinetics were confirmed by the linear correlation between dw and $\mathrm{NO}_{3}{ }^{-}$ concentration up to $330 \mu \mathrm{M} \mathrm{NO}_{3}^{-}$(Fig. 1A). The $\mathrm{NO}_{3}^{-}$ concentrations of 72 and $152 \mu \mathrm{M}$ applied in the main experiments were consequently within the optimal range of 40 to $330 \mu \mathrm{M}$.

Oxygen uptake, dn and dw were enhanced 2-, $3-$ and 5 -fold in the presence of 19800 ind. $\mathrm{m}^{-2}$ (Fig. 6). This differential stimulation showed that the amphipod burrows could not be considered as a simple extension of the sediment surface with associated processes. The 
observed pattern could be explained by differences between diffusional transport of $\mathrm{O}_{2}$ and $\mathrm{NO}_{3}^{-}$in the sediment surface and mass transport of $\mathrm{O}_{2}$ and $\mathrm{NO}_{3}{ }^{-}$ with water pumped through amphipod burrows: diffusion of $\mathrm{NO}_{3}{ }^{-}$at the sediment surface from the water column to the anoxic zone of denitrification is impeded by the presence of the oxic layer acting as a diffusion barrier. Model calculations confirmed by field studies in stream sediment have shown that the uptake of $\mathrm{NO}_{3}{ }^{-}$ relative to the $\mathrm{NO}_{3}{ }^{-}$concentration therefore should be about one-third of the $\mathrm{O}_{2}$ uptake relative to the $\mathrm{O}_{2}$ concentration (Christensen et al. 1990). In the amphipod burrows, however, $\mathrm{NO}_{3}{ }^{-}$and $\mathrm{O}_{2}$ should be consumed with the same efficiency provided that both $\mathrm{NO}_{3}{ }^{-}$and $\mathrm{O}_{2}$ are depleted from burrow water as it passes through the sediment. Bioturbation by Corophium volutator should therefore stimulate denitrification of $\mathrm{NO}_{3}^{-}$from the water 3 times more than $\mathrm{O}_{2}$ consumption, reasonably consistent with the actually observed 4 times higher stimulation (Fig. 6). Coupled nitrification-denitrification depends on the transport of $\mathrm{NO}_{3}{ }^{-}$from the oxic nitrification zone to the anoxic denitrification zone. Microsensor studies and flux measurements have indicated that nitrification activity usually is evenly distributed in the oxic surface zone of sediment, and about half the $\mathrm{NO}_{3}^{-}$produced diffuses down and is denitrified and half diffuses up into the overlying water column (Blackburn \& Henriksen 1983, Jensen et al. 1993). In the burrows, $\mathrm{NO}_{3}^{-}$diffusing out from the oxic nitrification zone of the walls is transported further through the burrow and is eventually denitrified; i.e. the coupling of nitrification and denitrification will be $100 \%$. Assuming that nitrification constitutes a constant fraction of sediment oxygen consumption, bioturbation should thus stimulate nitrification and oxygen consumption to the same extent, while coupled nitrification-denitrification should increase twice as much. The measurements indeed showed 2 times more stimulation of coupled nitrification-denitrification than of oxygen consumption in the presence of 19800 ind. $\mathrm{m}^{-2}$ (Fig. 6).

This study has shown that Corophium volutator increases not only the absolute rate of denitrification but also denitrification relative to oxygen consumption, particularly when $\mathrm{NO}_{3}{ }^{-}$from the overlying water is the prime source. $C$. volutator is one of the dominating species in the benthic fauna of Norsminde Fjord, with common densities of 6000 ind. $\mathrm{m}^{-2}$ and high densities up to 65000 ind. $\mathrm{m}^{-2}$ (Thorson 1975), and because of riverine discharge, the water phase concentration of $\mathrm{NO}_{3}^{-}$is often high (up to $600 \mu \mathrm{M}$ ) (Binnerup et al. 1992). This will indicate that different abundances of the amphipod through the same and successive years could have an important effect on nitrogen retention in the estuary.
Acknowledgements. This work was supported by the sectorial grant no. B/STEP-900024 from the European Economic Community and by the National Agency of Environmental Protection in Denmark in relation to HAV90-Marine Research Programme (no. 3. 27). We thank Lars B. Pedersen and Preben G. Sørensen for their skilled technical assistance.

\section{LITERATURE CITED}

Aller, R. C. (1988). Benthic fauna and biogeochemical processes in marine sediments: the role of burrow structures. In: Blackburn, T H., Sørensen, J. (eds.) Nitrogen cycling in coastal marine environments. John Wiley and Sons, Ltd, Chichester, p. 301-338

Aller, R. C., Yingst, J. Y. (1978). Biogeochemistry of tubedwellings: a study of the sedentary polychaete Amphitrite ornata. J. mar. Res. 36: 201-254

Binnerup, S. J., Jensen, K., Revsbech, N. P., Jensen, M. H., Sørensen, J. (1992). Denitrification, dissimilatory reduction of nitrate to ammonium, and nitrification in a bioturbated estuarine sediment as measured with ${ }^{15} \mathrm{~N}$ and microsensor techniques. Appl. environ. Microbiol. 58: 303-313

Birklund, J. (1977). Biomass, growth and production of the amphipod Corophium insidiosum Crawford, and preliminary notes on Corophium volutator (Pallas). Ophelia 16 $187-203$

Blackburn, T. H. (1993). Turnover of ${ }^{15} \mathrm{NH}_{4}{ }^{+}$tracer in sediments In: Kemp, P., Sherr, B. F., Sherr, E. B.. Cole, J. J. (eds.) Current methods in aquatic microbial ecology. Lewis Publishers, New York, p. 643-645

Blackburn, T. H., Henriksen, K. (1983). Nitrogen cycling in different types of sediments from Danish waters. Limnol. Oceanogr. 28: 477-493

Christensen, P. B., Nielsen, L. P., Serensen, J., Revsbech, N. P. (1990). Denitrification in nitrate-rich sediments: diurnal and seasonal variation related to benthic oxygen metabolism. Limnol. Oceanogr. 35: 640-651

Grasshoff, K., Erhardt, M., Kremling, K. (1983). Methods of seawater analysis. Basel Verlag Chemie, Deerfield Beach, FL

Henriksen, K., Hansen, J. I., Blackburn, T. H. (1980). The influence of benthic infauna on exchange rates of inorganic nitrogen between sediment and water. Ophelia Suppl. 1: $249-256$

Henriksen, K., Rasmussen, M. B., Jensen, A. (1983). Effect of bioturbation on microbial nitrogen transformations in the sediment and fluxes of ammonium and nitrate to the overlying water. Ecol. Bull. 35: 193-205

Hylleberg, J., Henriksen, K. (1980). The central role of bioturbation in sediment mineralization and element re-cycling. Ophelia Suppl. 1: 1-16

Jensen, K., Revsbech, N. P., Nielsen, L. P. (1993). Microscale distribution of nitrification activity in sediment determined with a shielded microsensor for nitrate. Appl. environ. Microbiol. 59: 3287-3296

Koike, I., Hattori, A. (1978). Simultaneous determination of nitrification and nitrate reduction in coastal sediments by a ${ }^{15} \mathrm{~N}$ dilution technique. Appl environ. Microbiol. 35: 853-857

Koike, I., Mukai, H. (1983). Oxygen and inorganic nitrogen contents and fluxes in burrows of the shrimps Callianassa japonica and Upogebia major. Mar. Ecol. Prog. Ser. 12: $185-190$

Kristensen, E. (1984). Effect of natural concentrations on nutrient exchange between a polychaete burrow in estuarine sediment and the overlying water. J. exp. mar. Biol. Ecol. 75: $171-190$ 
Kristensen, E. (1985). Oxygen and inorganic nitrogen exchange in a Nereis virens bioturbated sediment-water system. J. coast. Res. 1:109-116

Kristensen, E. (1988). Benthic fauna and biogeochemical processes in marine sediments: microbial activities and fluxes. In: Blackburn, T. H., Sorensen, J. (eds.) Nitrogen cycling in coastal marine environments. John Wiley and Sons, Ltd, Chichester, p. 275-299

Kristensen, E., Blackburn, T. H. (1987). The fate of organic carbon and nitrogen in experimental marine sediment systems: influence of bioturbation and anoxia. J. mar. Res. 45: $231-257$

Kristensen, E., Jensen, M. H., Aller, R. C. (1991). Direct measurement of dissolved inorganic nitrogen exchange and denitrification in individual polychaete (Nereis virens) burrows. J. mar. Res. 49:355-377

Kristensen, E., Jensen, M. H., Andersen, T K. (1985). The impact of polychaete (Nereis virens) burrows on nitrification and nitrate reduction in estuarine sediments. $\mathrm{J}$. exp. mar. Biol. Ecol. 85: 75-91

McLusky, D. S. (1969). The oxygen consumption of Corophium volutator in relation to salinity. Comp. Biochem. Physiol. 29: $743-753$

Nielsen, L. P. (1992). Denitrification in sediment determined from nitrogen isotope pairing. FEMS Microbiol. Ecol. 86: $357-362$

This article was submitted to the editor
Nixon, S. W., Oviatt, C. A., Hale, S. S. (1976). Nitrogen regeneration and the metabolism of coastal marine bottom communities. In: Andersen, J. M., MacFadyen, A. (eds.) The role of terrestrial and aquatic organisms in decomposition processes. Blackwell Scientific Publications, Oxford, $\mathrm{p}$. 269-283

Revsbech, N. P., Christensen, P. B., Nielsen, L. P., Sørensen, J. (1989). Denitrification in a trickling filter biofilm studied by a microsensor for oxygen and nitrous oxide. Water Res. 23 : $867-871$

Rhoads, D. C. (1974). Organism-sediment relations on the muddy sea floor. Oceanogr. mar. Bull. A. Rev. 12: $263-300$

Risgaard-Petersen, N., Rysgaard, S., Revsbech, N. P. (1993). A sensitive assay for determination of ${ }^{14} \mathrm{~N} /{ }^{15} \mathrm{~N}$ isotope distribution in $\mathrm{NO}_{3}^{-}$. J. Microb. Meth. 17: 155-164

Ryther, J. H., Dunstan W. M. (1971). Nitrogen, phosphorus, and eutrophication in the coastal marine environment. Science 171: 1008-1013

Seitzinger, S. P. (1980). Denitrification and $\mathrm{N}_{2} \mathrm{O}$ production in near-shore marine sediments. Geochim. Cosmochim. Acta 44: $1853-1860$

Thorson, G. (1975). Infaunaen, den jæune havbunds dyresamfund. In: Böcher, T. W. , Nielsen, C. O., Schou, A. (eds.) Danmarks Natur, Vol. III. Havet. Politikens Forlag, København, p. $82-166$

Manuscript first received: August 16, 1993

Revised version accepted: November 30, 1993 